\title{
O MAIS ALÉM DA ESCRITA NA OBRA “THE TICKET THAT EXPLODED” DE WILLIAM BURROUGHS
}

Pedro Teixeira Castilho*

RESUMO:

A escrita do autor americano William Burroughs é analisada levando em consideração a concepção de linguagem como um vírus e os desdobramentos desta concepção: o cut up $e$ o fold in. 0 livro The ticket that exploded é a fonte para demonstrar a prática de escrita do autor denunciando que Burroughs escreve subvertendo a ordem sintagmática das frases.

PALAVRAS-CHAVE: cut up, fold in, ordem sintâtica, palavra vîrus, linguagem.

A escrita de William Burroughs possui uma peculiaridade se levarmos em consideração os mecanismos de cut up e fold in presentes nas suas obras. Para tanto pretendo elucidar os mecanismos de cut up e fold in na sua escrita me concentrando em alguns fragmentos da obra The ticket that exploded para apresentar uma leitura que autoriza essa escrita em um campo que extrapola as concepções lingüísticas - cut up e fold in -, estabelecendo uma narrativa bastante veloz e desorganizada, na qual um enredo aparece e desaparece. Esse enredo constitui-se como um dispositivo que se desenrola com momentos de lucidez e clareza, mas, em outros, quando a narrativa do cut up torna-se mais rebuscada, a ficção pulveriza-se.

Enquanto "as imagens criadas pela leitura da obra podem constantemente ser arbitrárias e repulsivas, os padrões rítmicos das palavras, das sentenças e das narrativas são altamente selecionados produzindo uma sonoridade" (Lydenberg, 1987: 76).

* Mestre em Letras: Literatura e outros Sistemas Semióticos (Ârea de concentração: Teoria da Literatura), 2004. 


\section{EMTESE}

Belo Horizonte, v. 9, p. I-28I, dez. 2005

Se existe uma possibilidade de apontar o estilo desse autor, esta passaria pelo sentido que é dado ao enredo, aparecendo e desaparecendo, questionando a originalidade do texto (se o texto pertence a ele ou a outrem), palavras e frases que se repetem em capítulos diversos, como também palavras que saem de corpos e vozes sem corpos. Essa escrita é o estilo de Burroughs, que já se manifesta em sua primeira obra. Em alguns momentos, Burroughs chega até a citar a fonte de onde ele tirou o texto original; na página 23 da edição americana do livro Ticket ele cita "quote from Fury by Henry Kuttner page 143."

Burroughs é um autor da palavra, da palavra que deve ser expelida do corpo ou ingerida pelo corpo, como um vírus. Logo no primeiro capítulo de The ticket that exploded, a palavra toma algumas dimensões de matéria: "de fato a sua voz foi cortada em 24 vezes por segundo com o som de sua respiração e batimentos de seu coração e agora o meu corpo está convencido que a minha respiração e meu coração vão parar se sua voz parar" (Burroughs, 1965: 3). ou outra passagem, no segundo capítulo, na qual fica ainda mais clara a noção de materialidade da palavra, que ultrapassa a concepção de linguagem na episteme moderna: "o homem que usava aquela voz não tinha língua materna. Ele aprendeu o uso de uma ferramenta alienígena. As palavras flutuavam no ar atrás dele enquanto ele andava" (Burroughs, 1965: 9). A linguagem não é algo natural para Burroughs, a língua flutua atrás de corpos que não possuem língua materna, pois toda língua é estranha. Nota-se nessas duas passagens construções descritivas das palavras; quando a leitura avança, as construções do início do livro vão sendo substituídas por frases impactantes e desorganizadas gramaticalmente.

Esse caminho encontrado por Burroughs constitui uma descrição do enredo, palavras que flutuam sobre o sujeito, localizando a maneira que o leitor deve-se conduzir na leitura do livro, no segundo momento, a escrita torna-se rebuscada com os efeitos do cut up, frases que constituíam a descrição do enredo reaparecem; "o som da sua voz e sua imagem tremendo sobre o gravador são tão familiares para mim como os movimentos do meu intestino e o som da minha respiração e o batido do meu coração". na página 1 e, somente na página 50, o capítulo que a natureza virótica da linguagem é explicitado os sons do corpo são confundidos com a palavra reaparecendo as partes citadas anteriormente; 
"A palavra é cortada com o som de seu intestino e a respiração com o batido do coração. O primeiro passo é gravar os sons do seu corpo e começar a corta-lo em você mesmo" (Burroughs, 1965: 50).

É essa a questão literária de William Burroughs, a palavra tratada em sua materialidade. Essa concepção da palavra desdobra-se na escrita do autor. 0 prazer de ler a obra The ticket that exploded está em perceber as dimensões atribuídas à palavra, como também as conseqüências que Burroughs construiu a partir de seu conceito de linguagem. Robin Lydenberg recomenda "sermos temporariamente Burroughs" (Lydenberg, 1987: 73) na leitura do Ticket, mas isso não quer dizer que devamos ficar imersos em imagens de sexo e violência, uma acusação freqüente à escrita de Burroughs, mas sim que percebamos a relação desse autor com a linguagem que cria essas imagens. Ou seja, para Burroughs, sexo e violência são conseqüências da atuação parasitária da linguagem no corpo.

A escrita desse autor induz novos circuitos de sentidos que vão além de uma ordem sintagmática e lingüística, provocando um estranhamento no sujeito que 1ê. Ao mesmo tempo, uma familiaridade com o texto surge diante do sentido induzido pelo enredo.

Logo, a escrita desse autor é sua própria concepção de linguagem, que se constrói no seu estilo. Para ler o livro Ticket é necessário penetrar no texto e deixar os efeitos das palavras constituírem o enredo da obra. 0 leitor, então, deve desconectar-se das imagens do texto e entrar no próprio estilo de Burroughs. Não é apenas a atenção racional, cartesiana, aplicada à leitura de um texto, mas é importante perceber que as palavras têm uma exterioridade, como também uma materialidade, para se deixar possuir pela escrita do cut up. A insistência de Burroughs com a palavra virótica é exatamente a referência do leitor na construção do Ticket.

No capítulo "Do you love me?", Burroughs seleciona fragmentos de canções românticas americanas para justapor às frases de filmes pornográficos. No final do capítulo, essa justaposição intensifica-se, levando os personagens dessa parte, dois amantes, a um sentimento recíproco de incompletude. Na leitura desse fragmento, percebe-se uma ironia de Burroughs diante da relação 


\section{EM TESE}

Belo Horizonte, v. 9, p. I-28I, dez. 2005

entre os sexos, surgindo, repetidamente, essa frase, "eu explodi em um risada cósmica" (Burroughs, 1987: 43-45).

Todo o capítulo é construído por títulos e fragmentos de músicas populares americanas, - "Lovey lovey dovey... Do you love me? Love is para olvidar - Tell Laura oh jelly love you - i can ${ }^{-} t$ - got you under my skin on my mind (Burroughs, 1987: 144), a palavra love tem sua grafia adulterada pelo acréscimo de um "y", seguida de uma palavra criada pelos amantes para como uma forma de expressar carinho, dovey, juntamente com uma expressão trazida do espanhol, para olvidar, que aparece italizado no texto. Como se não bastasse, o autor adiciona um fragmento de uma música de Cole Porter, consagrada na voz de Frank Sinatra; além disso, o pessoal de primeira pessoa do singular vem grafado em minúscula, " $i$ ", contrariando a norma da língua inglesa; isso não ocorre a todo o momento, pois no início do livro esse pronome aparece na forma convencional, havendo a mudança a partir da metade do texto.

Todos as melodias e os efeitos sonoros do "Amor" partem da permutação do gemido sexual do planeta figura: Você me ama? - Mas eu explodi em uma risada cósmica - Velho conhecido seja esquecido? - Oh querida apenas uma fotografia? Mary eu te amo eu te amo você sabe que eu te amo? - De joelhos eu espero que você me ame também - eu correria até eu sentir o estremecimento de tempos atrás - Agora minha inspiração, mas, isto não vai ficar e nós seremos apenas uma fotografia - eu esqueci de você então? - eu não posso dormir olhos azuis se eu não tenho você - será que eu a amo? - eu te amo eu te amo coisa mais esplendida (Burroughs, 1965: 43 - 44)

Assim, depois de uma narrativa mais calma, o cut up vai ficando mais evidente, aparecendo uma narrativa mais caótica, que chega a uma conclusão previsível, a impossibilidade dos opostos se unirem.

Burroughs escreve misturando canções sentimentais americanas com depoimentos pornográficos, criando uma escrita que vai além da disposição aleatória de palavras. Essa escrita traz "buracos" que são preenchidos por pornografias, transformando a narrativa em uma questão sobre o amor.

Ilusões e imagens são criadas pelas palavras que vêm de fora, pois, essas palavras atacam, viroticamente, os seres humanos e instituem a concepção binária da diferença sexual. A diferença sexual é um efeito da virulência da linguagem, a relação homem/mulher só existe porque os corpos estão submersos na linguagem. Por um outro 1ado, segundo Burroughs, o pensamento binário estabelece 
o desejo de união que não pode ser nunca atingido porque os opostos nunca podem se transformar em um Won't be two.

$\mathrm{Na}$ leitura dessa obra de Burroughs, a relação do vírus com a sexualidade torna-se efetivamente clara no capitulo intitulado "operation rewrite", no qual o autor explicita a vinculação da palavra com o corpo, expondo a idéia de uma Outra Metade, a palavra, "uma invasão da área sexual tomando espaço"(Burroughs, 1965: 51).

0 enredo do livro de Burroughs gira em torno dessa Outra Metade (The Other Half, The Mob), a palavra. Esta constrói a subjetivação dos seres humanos e controla, pela ação virulenta, o prazer do orgasmo, os sentimentos do amor, o sexo oposto e o outro corpo.

0 erótico da obra de Burroughs é um erótico com a linguagem, a língua deve ser roçada e tocada pelo corpo sem mesmo saber quais são os limites da natureza viva da linguagem. Burroughs experimenta a relação das palavras com os corpos ao limite, construindo momentos inusitados. Um desprendimento do sujeito é a razão do erótico da palavra impactante sobre o corpo. Denunciando sua materialidade e sua virulência, a palavra é a contaminação de um corpo que pode ser adoecido por esse vírus mortificante da realidade sexual e do sujeito da enunciação.

A obra Ticket é escrita para resistir ao vício da palavra, um circuito de dominação que o autor pretende romper usando aquilo que ele mesmo criou, a invasão parasitária da palavra. 0 autor faz da palavra escrita por ele uma prática e uma saída para a questão colocada no próprio enredo.

Assim sendo, o corpo é explorado no seu limite, cortado e desmembrado em pedaços, o tempo traz um ritmo e uma quebra de padrões lingüísticos no qual a sintaxe aparece cheia de traços, parênteses e hífens.

Se a sintaxe é a constituição das frases dentro do discurso, bem como a relação lógica das frases entre si e a correta construção gramatical, nessa obra de Burroughs existe um desafio aos padrões lingüísticos. 0 sintagma, a construção lógica das frases, é contornado pela prática do cut up. Isso aparece quando Burroughs corta longas construções de frases de outros autores 


\section{EM TESE}

Belo Horizonte, v. 9, p. I-28I, dez. 2005

mantendo a maior parte da sintaxe do escrito original ocorrendo disjunções com menor freqüência. Mas, por outro lado, se o método do cut up for aplicado da maneira que Burroughs comumente postula, "um pequeno pedaço de papel sendo cortado em quatro partes iguais", as disjunções ocorrerão com mais freqüência e a sintaxe será comprometida.

Assim, dentro do texto de Burroughs, a realidade passa a ser um mosaico constituído na e pela fragmentação do texto. Esse movimento que o autor faz entre o involuntário e o voluntário, entre a memória e a amnésia, é uma estratégia com relação à organização lógica da sintaxe.

Desse modo, Burroughs afirma que o "corte e a manipulação provocam fortes reações eróticas" (Burroughs, 1965: 18), sem hesitar em convocar o leitor para a faceta erótica da linguagem. A memória mescla-se entre a realidade factual e a realidade psíquica, as cenas de personagens e de lugares se misturam umas com as outras. As palavras são assombradas por corpos desmembrados e anônimos - rostos, mãos e dedos.

As várias maneiras de ler essa obra de Burroughs apontam para um mais além da escrita. Entre elas, está a leitura de um enredo que aparece e desaparece na sua escrita, com uma gramática convencional e significados aparentemente decifráveis; uma outra possibilidade está em uma leitura hipnótica, no encantamento agramatical.

A narrativa de Burroughs não quer garantir nada para o leitor, ela não quer aparecer com um final construído. No último capítulo do livro Silence to say good bye, logo no inicio, dois personagens escutam a freqüência que sinaliza para a presença de uma vida parasítica - a presença parasitária da palavra que induz e constrói o sujeito, dando a ele uma sexualidade, um corpo, o tempo e a imagem: "todas as ações são pregravadas e dopadas e não têm vida que ficou para trás no presente chupado e seco por um corpo que anda resmungando através do pátio vazio sob filmes no céu de Marakesh" (Burroughs, 1965: 189), A narrativa continua a mudar e se retorcer como aparecia em outros capitulos: "lábios caem - silêncio para dizer adeus - olhe a ação B.J.? 0 Hassan I Sabbah realmente trabalha para a inteligência naval... Você está escutando B.J." 
(Burroughs, 1965: 202). Burroughs esclarece ou confunde o leitor ainda mais quando este se lembra que a última pergunta nos remete, novamente, ao primeiro capitulo, intitulado "See the action B.J.?", induzindo a leitura para um final, que pode se constituir como uma espiral ou um círculo.

Depois desse último capítulo, Burroughs inclui um desenho de seu amigo Brion Gysin, feito a partir da frase "Silence to say good bye", seguido de um ensaio de Burroughs, adicionado depois da primeira edição, no qual ele propõe ao leitor mecanismos que The possibilitam escapar da linguagem. Dessa forma, 0 desenho de Gysin começa a se dissolver e a brincar com as palavras que compõem o título do capítulo, enquanto Burroughs descreve novas maneiras de se relacionar com as palavras. Entre elas, está uma frase escrita com espaços em branco "cut the prerecordings into air into thin air" (Burroughs, 1965: 217) As palavras perdem as pontuações, como também desaparecem as letras maiúsculas, os hífens, as inflexões e a violência, e as frases imperativas dão o tom desse ensaio.

Em resumo, na obra The ticket that exploded, Burroughs instaura na língua uma infecção virótica causada por um organismo parasita, a língua captura os corpos, sendo construída pelo autor uma terceira dimensão, estabelecida entre as palavras e os corpos. No apêndice do livro, "The Invisible Generation", escrito a quatros mãos, com o artista plástico Brion Gysin, Burroughs propõem diferentes maneiras para que a influência da linguagem sobre os corpos seja atenuada, como, por exemplo, tocar uma fita cassete de traz para frente, "sendo assim uma pessoa pode aprender a "desdizer" aquilo que foi dito... tal exercício deixa as pessoas livres de palavras que podem trancá-las". Aparece, enfim, uma variedade de métodos que extraem a relação do corpo parasitado pela palavra: colocar as fitas cassetes em diferentes velocidades para se escutar novas palavras sendo formadas e poder juntálas com sons dos corpos e de animais.

Para o autor, ainda nesse mesmo capítulo, a palavra começa a ser interrogada e investigada. Para Burroughs, podemos descobrir mais sobre o sistema psíquico e conseguir maior controle sobre suas reações; ele recomenda que escutemos nossas vozes em fitas cassetes recém-gravadas para que saibamos quem realmente somos, e, ainda, que escutemos as fitas de hoje e de ontem, para vermos quais impressões esses sons podem trazer. Logo depois dessa passagem, ele pergunta: 


\section{EM TESE}

Belo Horizonte, v. 9, p. I-28I, dez. 2005

quem é que te programa?

Quem decide que cassete deve tocar de novo no presente?

Quem toca novamente suas velhas humilhações e vence te segurando no presente gravado? (Burroughs, 1965: 223)

Nota-se que Burroughs deposita a palavra dentro de um campo outro, em sua própria autonomia, a partir da qual pode controlar e manejar o corpo humano, como um ventríloquo, criando na relação palavra/corpo um mais além da escrita.

ABSTRACT :

The writing of an american writer William Burroughs is analyzed upon the viral conception of language and the changes of this conception: the cut up and the fold in. The book the ticket that exploded is the source to show the writing of William Burroughs denouncing that Burroughs subvert the syntactic order of the phrases.

KEY WORDS: cut up, fold in, syntactic order, word virus, language.

REFERÊNCIAS BIBLIOGRÁFICAS

BURROUGHS, William S. The ticket that exploded. New York: Grove Press, 1965.

LYDENBERG, Robin. Word Culture: radical theory and practice in William S. Burroughs' fiction. Urbana: University of Illionois Press, 1987. 